1974; Jordan 1974 b). Wastell et al. (1972) however, reported two cases of recurrent ulcer within a few months of H.S.V. in a small series, and 22\% of Kronborg and Madsen's (1975) 50 patients developed recurrent ulceration within four years of H.S.V. The early postoperative insulin test, however, showed that $58 \%$ of Kronborg and Madsen's patients and $28 \%$ of those of Wastell et al., had incomplete vagotomy. Since there is a good correlation between insulin positivity soon after vagotomy and subsequent recurrent ulceration (Bell et al., 1965; Johnston et al., 1967; Baron, 1973; Kennedy et al., 1973) it is perhaps not surprising that the incidence of recurrent ulceration after H.S.V. in these series was high.

Hence our conclusion-that the addition of antrectomy to vagotomy is unnecessary when patients with hypersecretion of acid are treated by H.S.V.- -is valid only if the H.S.V. is shown to be complete either at the time of operation or on insulin testing soon after operation. In view of the greater risk to life and the long-term disadvantages of antrectomy we think it best to avoid antrectomy but to spare no effect to ensure that the vagotomy of the parietal cell mass is complete at operation. Using operative techniques described previously (Johnston and Wilkinson, 1970; Goligher, 1974) we kept the incidence of incomplete vagotomy at $7 \%$. The ability of junior members of staff, who now perform many of the H.S.V. operations, to achieve a complete vagotomy differs little from that of the consultants. Hence the technical aspects of this operation are well within the capability of any surgeon who is prepared to study the technique and begin using H.S.V. cautiously in slim patients.

It is important that the completeness of the parietal cell vagotomy should be monitored. Such a "quality control" is provided after operation by the insulin test. If this test gives positive results in no more than $10-15 \%$ of patients probably nothing more need be done because the incidence of recurrent ulceration should be low. If the incidence of incomplete vagotomy is higher, however, the operative technique should be reassessed and consideration given to the use of some intraoperative test. Such tests have not secured wide acceptance, but they are unquestionably a more rational form of quality control than the insulin test, because if the vagotomy is incomplete a determined effort can be made to complete it, and the outcome of the surgeon's endeavours can be assessed once more. Such intraoperative tests are the Burge test (Burge and Vane, 1958; Burge and Frohn, 1969) and the Grassi test (Grassi, 1971). It is better to use these tests than to subject a significant proportion of patients to an unnecessary and potentially harmful antrectomy.

We thank Mr. A. R. Wilkinson, Mr. C. S. Humphrey, Mr. R. B. Smith, and Dr. P. J. Lyndon, who performed the tests of acid secretion. I. R. Pickford was spending an elective studentship in the university department of surgery.

\section{References}

Amdrup, E. et al. (1974). Annals of Surgery, 180, 279.

Baron, J. H. (1973). In Vagotomy on Trial, ed. A. G. Cox and J. AlexanderWilliams, p. 7. London, Heinemann.

Bell, P. R. F. et al. (1965). Lancet, 2, 978.

Bruce, J.et al. (1959). Fournal of the Royal College of Surgeons of Edinburgh, 4,85 .

Burge, H., and Vane, J. R. (1958). British Medical fournal, 1, 615.

Burge, H., and Frohn, M. J. N. (1969). British Fournal of Surgery, 56, 452. Cox, A. G., (1968). British Medical fournal, 1, 288.

Cox, A. G., Spencer, J., and Tinker, J. (1969). In After Vagotomy, ed. J. A. Williams and A. G. Cox, p. 120. London, Butterworths.

Fawcett, A.N., Johnston, D, and Duthie, H.L. (1969). British fournal of Surgery, 56, 111.

Goligher, J. C.e et al., (1968). British Medical fournal, 2, 781.

Grassi, G. (1971). British fournal of Surgery, 58, 187.

Grassi, G. et al. (1973). Surgery, Gynecology and Obstetrics, 136, 726.

Herrington, J. L., jun. (1969). In Surgery of the Stomach and Duodenum, ed. H. N. Harkins and L. M. Nyhus, 2nd edn., p. 575. Boston, Little,
Brown and Co.

Hollander, F. (1948). Gastroenterology, 11, 419.

Humphrey, C. S. et al. (1972). British Medical fournal, 3, 785.

Johnston, D. et al. (1967). British fournal of Surgery, 54, 831.

Johnston, D., and Jepson, K. (1967). Lancet, 2, 585 .

Johnston, D. et al. (1972). British Medical fournal, 3, 788.

Johnston, D. et al. (1972). British Medical fournal, 3,

Johnston, D. et al. (1973 a). Gastroenterology, 64, 1.

Johnston, D., and Wilkinson, A. R. (1969). British fournal of Surgery, 56, 626.

Johnston, D., and Wilkinson, A. R. (1970). British fournal of Surgery, 57, 289.

Jordan, P. H. Jun. (1974 a). Annals of Surgery, 180, 259.

Jordan, P. H. Jun. (1974 b). Archives of Surgery, 108, 434.

Kennedy, F. et al. (1973). British Medical fournal, 2, 71.

Kronborg, O. (1972). Scandinavian fournal of Gastroenterology, 7, 423.

Kronborg, O. (1974). Gut, 15, 714.

Kronborg, O., and Madsen, P. (1975). Gut. In Press.

Liavag, I., and Roland, M. (1973). Scandinavian fournal of Gastroenterology, 8, Suppl. 20, p. 10.

Moberg, S., and Hedenstedt, S. (1973). Scandinavian fournal of Gastroenterology, 8, Suppl. 20, p. 9 .

Robbs, J. V.et al. (1973). British fournal of Surgery, 60, 601.

Ross, B., and Kay, A. W. (1964). Gastroenterology, 46, 379.

Small, W. P. et al. (1967). British fournal of Surgery, 54, 838.

Small, W. P. (1973). Clinics in Gastroenterology, 2, 427.

Smithwick, R. H., Harrower, H. W., and Farmer, D. A. (1961). American fournal of Surgery, 101, 325.

Wastell, C. et al. (1972). British Medical fournal, 1, 28.

\title{
Depression of Sublingual Temperature by Cold Saliva
}

\author{
R. E. G. SLOAN, W. R. KEATINGE
}

British Medical fournal, 1975, 1, 718-720

\begin{abstract}
Summary
Sublingual and oesophageal temperatures were compared at various air temperatures in 16 subjects. In warm air $\left(25-44^{\circ} \mathrm{C}\right)$ sublingual temperatures stabilized within $\pm 0.45^{\circ} \mathrm{C}$ of oesophageal temperatures, but in air at room temperature $\left(18-24^{\circ} \mathrm{C}\right)$ they were sometimes as much as $1 \cdot 1^{\circ} \mathrm{C}$ below and in cold air $\left(5-10^{\circ} \mathrm{C}\right)$ as much as $4 \cdot 4^{\circ} \mathrm{C}$ below oesophageal readings. The sublingualoesophageal temperature difference in cold air was
\end{abstract}

\footnotetext{
Department of Physiology, London Hospital Medical College, London E1 2AD

R. E. G. SLOAN, M.B., B.sc., Lecturer in Physiology

W. R. KEATINGE, M.B., PH.D., Professor of Physiology
}

greatly reduced by keeping the face warm, but it was not reduced in two patients breathing through tracheostomies and thereby eliminating cold air flow from the nose and pharynx. Parotid saliva temperature was low and saliva flow high during exposure, and cold saliva seemed to be mainly responsible for the erratic depression of sublingual temperature in the cold. These results indicate hazards in the casual use of sublingual temperatures, and indicate that external heat may have to be supplied to enable them to give reliable clinical assessments of body temperature.

\section{Introduction}

The sublingual reading normally used for routine clinical measurement of body temperature is depressed in cold air and therefore unsuitable for assessing hypothermia (Pembrey, 1898; Fox et al., 1971), though it is generally considered reliable in air 
at normal room temperature $\left(20^{\circ} \mathrm{C}\right)$. For example, Cranston et al. (1954) found that the discrepancy between the mean sublingual and oesophageal temperatures of a group of recumbent subjects was only $0.09^{\circ} \mathrm{C}$, but Tanner (1951) and Fox et al. (1971) recorded individual sublingual readings about $1.0^{\circ} \mathrm{C}$ below rectal temperature. Rectal temperature may itself be misleading, and we re-examined the reliability of sublingual temperature by assessing the limits of its discrepancy from central blood temperature during exposure of the head to air at various temperatures. We also investigated the way that external cooling depressed sublingual temperature after preliminary studies showed that cold saliva could be felt to enter the mouth from the parotid duct in cold environments.

\section{Methods}

The subjects were 14 medical students and nurses aged 18-30 years and two patients with permanent tracheostomies. They were warmly clothed but bareheaded. They each sat on a chair in a room that could be maintained within $0.5^{\circ} \mathrm{C}$ of any temperature between 0 and $50^{\circ} \mathrm{C}$. The air was slowly moving at a rate of $0.5 \pm 0.2 \mathrm{~m} / \mathrm{sec}$ to mimic conditions in clinical waiting areas.

Oesophageal temperature, which closely follows central blood temperature (Cooper and Kenyon, 1957; Hercus et al., 1959), was used as a reference. Thermistor probes (Light Laboratories, Ltd.) accurate to $\pm 0.05^{\circ} \mathrm{C}$ were used to monitor sublingual and oesophageal temperatures. Their $99 \%$ response times when they were initially at $18^{\circ} \mathrm{C}$ and plunged into stirred water at $37^{\circ} \mathrm{C}$ were less than 15 seconds. The sublingual probe was pushed against the root of the tongue, and the lips were closed and sealed with tape when necessary. Since sublingual temperature may take 10-20 minutes to stabilize after the probe is inserted and the mouth closed (Cranston et al., 1954) sublingual probes were always left in position for 30 minutes. The oesophageal probe was inserted through a nostril to a depth judged by external measurement to bring the sensor opposite the middle of the lower third of the sternum.

Parotid saliva was collected by a Lashley cannula (Lashley, 1916) held by suction to the inner surface of the cheek. Its temperature was monitored by an alumel-chromel thermocouple (Saxonia Wire Co. Ltd.) with a reference junction in a constant temperature water bath; the thermojunction's $99 \%$ response time was 22 seconds when it was initially at $18^{\circ} \mathrm{C}$ and plunged into water at $37^{\circ} \mathrm{C}$. Saliva was collected over successive six-minute periods into plastic containers which were weighed before and after collection to give mean salivary flow.

\section{Results}

Sublingual-oesophageal Temperature Differences.-In air at $18-24^{\circ} \mathrm{C}$ both sublingual and oesophageal temperatures stabilized within 30 minutes after the probes were inserted, and neither reading changed by more than $0.15^{\circ} \mathrm{C}$ during the last 10 minutes of this time in any of 35 experiments on 14 subjects. When one person then went into air at $3.5^{\circ} \mathrm{C}$ the oesophageal temperature changed little but sublingual temperature, initially $0.75^{\circ} \mathrm{C}$ below oesophageal, fell by $1.3^{\circ} \mathrm{C}$ to a level $2 \cdot 3^{\circ} \mathrm{C}$ below oesophageal after 30 minutes and was still falling at the end of this time. The sublingual-oesophageal temperature differences at the end of 75 30-minute exposures to air at different temperatures are shown in fig. 1. Though oesophageal temperatures were much the same in all air temperatures sublingual temperatures were generally lower than oesophageal ones in air colder than $24^{\circ} \mathrm{C}$. At $5-10^{\circ} \mathrm{C}$ sublingual temperatures were often $2 \cdot 5-4 \cdot 5^{\circ} \mathrm{C}$ below oesophageal levels, and though at normal room temperature $\left(18-24^{\circ} \mathrm{C}\right)$ they were often close to and in one case slightly above oesophageal readings they were sometimes as much as $0 \cdot 9-1 \cdot 1^{\circ} \mathrm{C}$ below. Only in air at $25-44^{\circ} \mathrm{C}$ were sublingual temperatures consistently within $0.45^{\circ} \mathrm{C}$ of oesophageal temperatures.

Effect of Protecting Face.-Six subjects sat in air at $3 \cdot 5-10^{\circ} \mathrm{C}$ for 30 minutes with a 30-mm layer of cotton wool round their heads and faces. Their noses and mouths were left clear. After 30 minutes the mean oesophageal temperature ( \pm S.E. $)$ was $36.93 \pm 0.13^{\circ} \mathrm{C}$, and the sublingual temperature was only $0.19 \pm 0.13^{\circ} \mathrm{C}$ lower; it had been $1.33 \pm 0.21^{\circ} \mathrm{C}$ lower in the similar experiments with the faces unprotected.

Elimination of Cold Air Flow from Upper Airways.-The effect of exposure to cold air on two patients breathing through permanent trache- ostomies with no air flow through the nose or mouth is shown in fig. 2. The sublingual temperature fell considerably during exposure to cold in both cases. Oesophageal temperature was not measured.

Temperature and Flow Rate of Saliva.-Parotid saliva was collected during exposure of the face to air at $18-24^{\circ} \mathrm{C}$ for 30 minutes and then to air at $9-11^{\circ} \mathrm{C}$ for another 30 minutes. Saliva temperature fell and saliva flow increased greatly in the cold air. In six such experiments mean saliva and sublingual temperatures ( $t$ S.E.) were respectively $36.60 \pm 0.09^{\circ} \mathrm{C}$ and $36.90 \pm 0.04^{\circ} \mathrm{C}$ after 30 minutes at $18-24^{\circ} \mathrm{C}$ and $35 \cdot 15 \pm 0 \cdot 28^{\circ} \mathrm{C}$ and $36 \cdot 35 \pm 0 \cdot 13^{\circ} \mathrm{C}$ after 30 minutes at $9-11^{\circ} \mathrm{C}$. Saliva flow rates were $25.3 \pm 4.2 \mathrm{mg} / \mathrm{min}$ in the last six minutes at $18-24^{\circ} \mathrm{C}$ and $59 \cdot 6 \pm 5 \cdot 1 \mathrm{mg} / \mathrm{min}$ in the last six minutes at $9-11^{\circ} \mathrm{C}$.

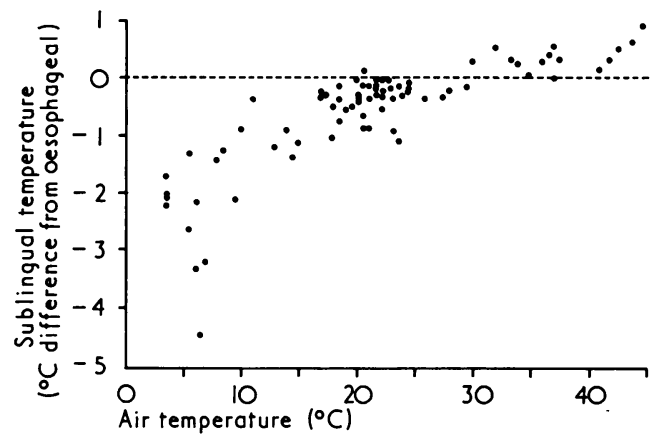

FIG. 1-Sublingual-oesophageal temperature differences after 30 minutes in air at various temperatures. Seventyfive studies.

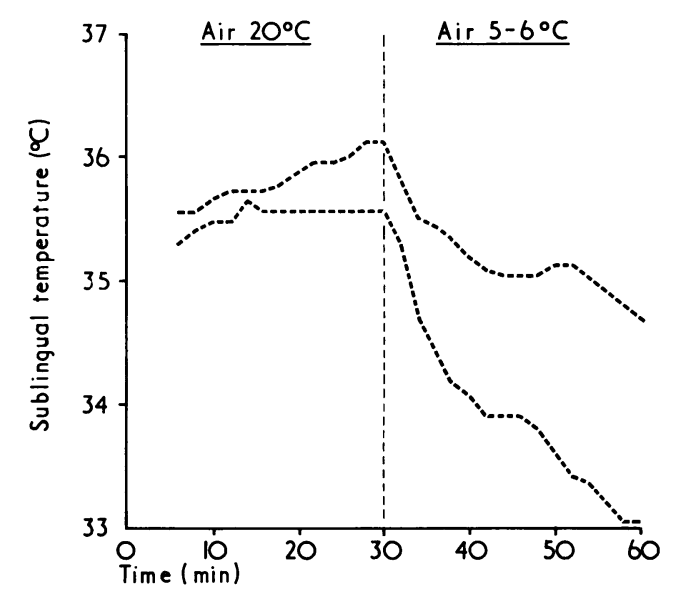

FIG. 2-Effect of exposing head to cold air on sublingual temperatures of man (upper trace) and woman (lower trace) breathing through tracheostomies.

\section{Discussion}

The clinically important finding was the existence of variable and often large depressions of sublingual temperature with respect to oesophageal temperature when subjects were in an environment where the air was cooler than $24^{\circ} \mathrm{C}$ even though the probes had been in place with the mouth closed for at least 30 minutes. The parotid duct runs just under the skin of the cheek, and parotid saliva reached the mouth at a low temperature when the face was cooled, while protection of the face greatly reduced the fall in sublingual temperature. Flow of cold parotid saliva to the sublingual region therefore seems to have been the main cause of sublingual cooling. The degree of this cooling must depend on saliva flow rate, and exposure to cold can itself increase the flow (Dorodnitsina, 1937; Shannon, 1966; Louridis et al., 1970). We found that cold did substantially increase this flow, which explains the disproportionately large depression of sublingual temperature in air below $10^{\circ} \mathrm{C}$. The size of this depression amply confirms previous evidence that sublingual temperature is unreliable in very cold surroundings, but the 
finding that sublingual temperature was sometimes depressed by $1.1^{\circ} \mathrm{C}$ even in a normal clinical environment is perhaps more important. The possible consequences, for example, of relying on a misleading sublingual reading of $36.4^{\circ} \mathrm{C}$ in a case of appendicitis with a true central body temperature of $37.5^{\circ} \mathrm{C}$ need no emphasis.

In air above $25^{\circ} \mathrm{C}$ sublingual temperature readings were close to oesophageal ones $\left( \pm 0.45^{\circ} \mathrm{C}\right)$. Maintenance of room temperature above this level might therefore seem the simplest way of obtaining reliable routine clinical measurements of body temperature. Such high environmental temperatures are most uncommon, however, and probably often unacceptable in British homes and waiting rooms. At a time of growing energy shortages there is a strong case for adopting a method of measuring body temperature that will be reliable in colder air.

Rectal temperature is inconvenient to measure and lags seriously when body temperature changes (Mellette, 1950; Cooper and Kenyon, 1957), as presumably does urine temperature (Fox et al., 1971). Oesophageal probes are too uncomfortable for routine outpatient use. Local warming of the face would allow reliable sublingual readings if it was well controlled. A procedure that might prove satisfactory for monitoring is to measure external aural canal temperature while a simple servocontrolled heating device keeps the outer ear at the same temperature. The aural canal probe can then give readings to within $0.35^{\circ} \mathrm{C}$ of oesophageal temperature (Keatinge and Sloan, 1973, 1975), though stabilization is slow from the cold state. A similar device has been shown to give reliable results in the newborn infant (Cross and Stratton, 1974).

We are indebted to the subjects for their co-operation, Professor R. L. Speirs for advice on the collection of parotid saliva, Mr. T. G. Barnett for constructing the thermocouple apparatus, and Mr. A. W. Morrison for permission to study the two subjects who were under his care.

\section{References}

Cooper, K. E., and Kenyon, J. R. (1957). British fournal of Surgery, 44, 616 Cranston, W. I., Gerbrandy, J., and Sneli, E. S. (1954). Fournal of Physiology, $126,347$.

Cross, K. W., and Stratton, D. (1974). Lancet, 2, 1179.

Dorodnitsina, A. A. (1937). Fiziologicheskii Zhurnal SSSR, 27, (1), 111 Fox, R. H., et al. (1971). Lancet, 1, 424.

Hercus, V., Cohen, D., and Bowring, A. C. (1959). British Medical fournal, 1,1439

Keatinge, W. R., and Sloan, R. E. G. (1973). Fournal of Physiology, 234, 8P. Keatinge, W. R., and Sloan, R. E. G. (1975). Fournal of Applied Physiology. In press.

Lashley, K. S. (1916). Journal of Experimental Psychology, 1, 461.

Louridis, et al. (1970). Fournal of Dental Research, 49, 1136.

Mellette, H. C. (1950). American fournal of Physiology, 163, 734.

Pembrey, M. S. (1898). Textbook of Physiology, ed E. A. Schafer, p. 786. London, Pentland.

Shannon, I. L. (1966). Archives of Oral Biology, 11, 451.

Tanner, J. M. (1951). Yournal of Physiology, 115, 391.

\section{MEDICAL MEMORANDA}

\section{Lymphoma Presenting as "Idiopathic" Juvenile Osteoporosis}

\author{
J. A. CHILD, I. E. SMITH
}

British Medical fournal, 1975, 1, 720-721

Bone involvement in the lymphomas is well recognized, though primary and more especially diffuse disease of bone is unusual. Osteoporosis principally of the axial skeleton with gross changes in the spine must be extremely rare as a presenting manifestation of lymphoma and has not been documented. For these reasons the following case is reported.

\section{Case History}

A 14-year-old prepubertal boy was immobilized in traction for 10 weeks in March 1972 after a motor-cycle accident in which he fractured his right femur. He was subsequently mobilized and discharged home. He returned to school for a month but then developed pain in the hips, back, and shoulders. By February 1973 he had developed kyphosis, and $x$-ray films showed marked osteoporosis with collapsed vertebrae. His plasma calcium was $2.75 \mathrm{mmol} / 1(11 \mathrm{mg} / 100 \mathrm{ml})$ and urinary calcium $146.2 \mathrm{mmol} / 1(585 \mathrm{mg} / 100 \mathrm{ml})$. The conclusion was that these changes could have been due to immobilization.

Physiotherapy resulted in some improvement with a gradual fall

Royal National Orthopaedic Hospital, London W1N 6AD.

J. A. CHILD, M.D., M.R.C.P., Senior Medical Registrar (Present appointment: Consultant Clinical Haematologist, General Infirmary, Leeds)

Royal Marsden Hospital, Sutton, Surrey

I. E. SMITH, M.R.C.P., Medical Registrar in urinary calcium excretion but progress seemed slow, and in June 1973 he was transferred to the metabolic unit of the Royal National Orthopaedic Hospital, Stanmore. At that time the positive findings were slight upper thoracic kyphosis and tender lumbar vertebrae. $X$-ray films showed severe reduction in bone density, chiefly confined to the axial skeleton (fig. 1). Blood values were: calcium $2.73 \mathrm{mmol} / 1$ $(10.9 \mathrm{mg} / 100 \mathrm{ml})$, phosphorus $1.45 \mathrm{mmol} / 1(4.5 \mathrm{mg} / 100 \mathrm{ml})$, alkaline phosphatase $108 \mathrm{~K} . A$. units $/ 1$, urea $4.4 \mathrm{mmol} / 1(27 \mathrm{mg} / 100 \mathrm{ml})$,

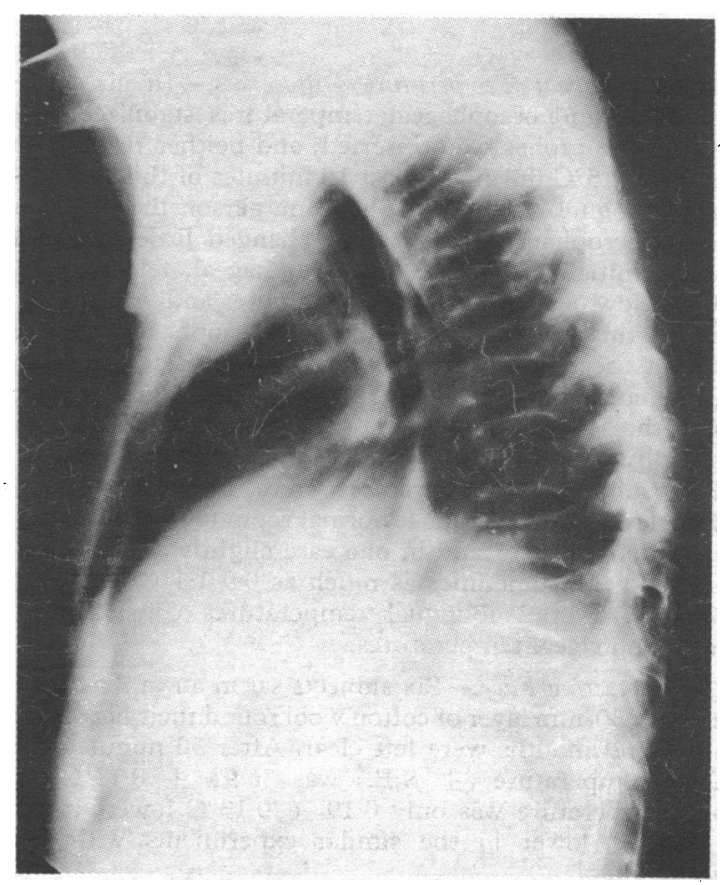

FT. 1-X-ray film taken June 1973 showing severe reduction in spinal bone density with vertebral collapse. 